\title{
Pengaruh Paket Edukasi HbsAg terhadap Pengetahuan dan Sikap Ibu Hamil Trisemester 1 tentang HbsAg
}

\author{
Nailah Islahiyah ${ }^{1}$, Kholisotin $^{1}$, Yuana Dwi Agustin ${ }^{2}$ \\ ${ }^{1}$ Universitas Nurul Jadid, Jl. PP Nurul Jadid, Dusun Tj. Lor, Karanganyar, Kecamatan \\ Paiton, Probolinggo, Jawa Timur \\ ${ }^{2}$ Universitas Bondowoso, Jl. Diponegoro No.247, Selatan Sawah, Desa Kota kulon, \\ Kecamatan Kota, Kabupaten Bondowoso, Jawa Timur \\ Email: nailahislahiyah@gmail.com
}

$\begin{array}{ll}\text { Diterima tanggal } & : 15 \text { April } 2020 \\ \text { Direvisi tanggal } & : 21 \text { Mei } 2020 \\ \text { Dipublikasikan tanggal } & : \text { 11 Juni } 2020\end{array}$

\begin{abstract}
Abstrak
Latar Belakang dan Tujuan: Kejadian infeksi virus hepatitis B pada ibu hamil menjadi perhatian khusus, karena selain dapat menyebabkan masalah kesehatan pada ibu, juga dapat menularkan pada bayi yang dikandungnya, terutama pada proses kelahiran. Tujuan dari penelitian ini adalah untuk mengetahui pengaruh paket edukasi HbsAg terhadap pengetahuan dan sikap ibu hamil trimester 1 tentang HbsAg.
\end{abstract}

Metode: Penelitian ini menggunakan desain penelitian pre eksperimen dengan pendekatan One Group Pretes-Posttest, dengan menggunakan kuesioner, sampel pada penelitian sebanyak 35 responden dengan menggunakan tekhnik total sampling.

Hasil: Mayoritas responden berusia 17-25 tahun sejumlah 19 responden $(54,29 \%)$, sebagian besar ibu primipara sejumlah 23 responden $(65,71 \%)$, tingkat pendidikan ibu sebagian besar SMP sebanyak 14 responden (40\%), dan sebagian besar sebagai ibu rumah tangga sejumlah 21 responden (60\%), tingkat pengetahuan ibu tentang $\mathrm{HbsAg}$ sebelum diberikan intervensi mayoritas kurang sejumlah 18 responden $(51,43 \%)$, tingkat pengetahuan setelah intervensi mengalami peningkatan yaitu mayoritas pengetahuan baik sebanyak 24 responden $(68,57 \%)$, sikap ibu sebelum intervensi mayoritas negatif sebanyak 21 responden (60\%), sikap setelah intervensi mengalami peningkatan menjadi positif sejumlah 32 repsonden $(91,43 \%)$. Hasil uji Wilcoxone diketahui $p$ value $0,000<0,05$ yang berarti ada perbedaan pengetahuan dan sikap ibu hamil Trimester 1 tentang HBsAg sebelum dan setelah intervensi.

Simpulan dan Implikasi: Paket edukasi HbsAg dapat meningkatkan pengetahuan dan sikap ibu hamil trimester 1 tentang HbsAg. Dengan demikian maka paket edukasi ini dapat digunakan oleh petugas kesehatan sebagai salah satu bentuk intervensi dalam meningkatkan pengetahuan dan sikap ibu hamil agar memahami pentingnya $\mathrm{HbsAg}$.

Kata Kunci: Edukasi pada ibu hamil; HbsAg; Pengetahuan; Sikap

Sitasi: Husnaniyah D, Yulyanti D \& Rudiansyah. (2020). Hubungan tingkat pendidikan ibu dengan kejadian stunting. The Indonesian Journal of Health Science. 12(1), 65-75

Copyright: (C) 2020 Husnaniyah et al. This is an open-access article distributed under the terms of the Creative Commons Attribution License, which permits unrestricted use, distribution, and reproduction in any medium, provided the original author and source are credited.

Diterbitkan Oleh: Universitas Muhammadiyah Jember

ISSN (Print): 2087-5053

ISSN (Online): 2476-9614 


\begin{abstract}
Background: The incidence of hepatitis B virus infection in pregnant women is of particular concern, because in addition to causing health problems in the mother, it can also transmit to the baby she is carrying, especially during the birth process. The purpose of this study is to determine the effect of HBsAg education packages on the knowledge and attitudes of 1st trimester pregnant women about HBsAg.

Methods: This study used a pre-experimental research design with the One Group Pretest-Posttest approach, using a questionnaire, the sample of the study was 35 respondents using total sampling technique.

Resluts: Most of respondents aged 17-25 years were 19 respondents (54.29\%), most of the primiparous mothers were 23 respondents (65.71\%), the education level of the mothers was mostly junior high school as many as 14 respondents (40\%), and most of them were mothers. There were 21 respondents (60\%), the mother's level of knowledge about HBsAg before being given intervention was less than 18 respondents (51.43\%), the level of knowledge after the intervention had increased, namely the majority of good knowledge was 24 respondents (68.57\%), the majority of mothers' attitudes before the intervention were negative as many as 21 respondents (60\%), the attitudes after the intervention increased to 32 respondents (91.43\%). The results of the Wilcoxone test showed that the $p$ value was $0.000<0.05$, which means that there were differences in knowledge and attitudes of 1st trimester pregnant women about HBsAg before and after the intervention.

Conclusion: HBsAg education package can increase knowledge and attitudes of pregnant women in trimester 1 about HBsAg. Thus, this educational package can be used by health workers as a form of intervention in increasing the knowledge and attitudes of pregnant women in order to understand the importance of HBsAg.
\end{abstract}

Keywords: Attitude; HbsAg; Knowledge; Pregnant women education;

\section{PENDAHULUAN}

Kehamilan

merupakan

peristiwa yang membahagiakan bagi seorang wanita di dalam pernikahan. Pada masa kehamilan terjadi beberapa perubahan baik secara fisik maupun fisiologis. Perubahan ini terjadi karena tubuh mempersiapkan diri untuk proses melahirkan serta untuk perkembangan janin. Perubahan yang terjadi dapat mempengaruhi sistem dalam tubuh yang berdampak terhadap fisiologis bagian-bagian tubuh (Abdul Gani Soulissa, 2014).

Kejadian infeksi virus hepatitis
B pada ibu hamil menjadi perhatian khusus, karena selain dapat menyebabkan masalah kesehatan pada ibu, juga dapat menularkan pada bayi yang dikandungnya, terutama pada proses kelahiran. Ibu hamil yang mengalami infeksi virus hepatitis B akut dapat mengalami insiden prematuritas, berat badan lahir rendah, rupture varises esophagus, pendarahan setelah persalinan, gagal hati, ikterus, dan rupture aneurisma splenika. Obi pada tahun 2016 melaporkan bahwa sekitar 2\%-12\% ibu hamil merupakan penderita hepatitis B 
kronis dan keberadaan virus hepatitis B dalam kehamilan berkontribusi terhadap tingginya transmisi vertikal dari ibu ke bayi. Menurut WHO, sekitar $90 \%$ bayi yang terinfeksi pada tahun pertama kehidupannya berlanjut menjadi hepatitis kronis (Notoatmodjo, 2012b)

Di dunia ini diperkirakan terdapat 240 juta orang telah menjadi carrier hepatitis B. Dari jumlah Itu, sekitar 200 juta orang terdapat di beberapa Negara Asia. Sementara itu angka kejadian yang sama disejumlah Negara Asia Tenggara seperti, Indonesia (10\%), Malaysia $(5,3 \%)$, Brunai $(6,1 \%)$, Thailand (8\%-10\%), Filipina (3,4\%-7\%). Angka insidens penyakit Hepatitis B di Indonesia pada tahun 2012 - 2017 mengalami peningkatan. Pada tahun 2012 terjadi 12.990 kasus per 10.000 penduduk dengan angka insiden sebesar $0,6 \%$. Sedangkan 5 tahun kemudian tepatnya pada tahun 2017 dijumpai lonjakan kasus hepatitis B sebanyak 21.713 kasus per 10.000 penduduk dengan angka insidens sebesar 9.7\% (DepKes RI, 2017).

Propinsi Jawa Timur (prevalensi $4,08 \%$ ) menempati posisi ketiga dalam urutan prevalensi tertinggi infeksi virus hepatitis B pada ibu hamil. Kabupaten Bondowoso sejak Bulan Januari sampai dengan desember tahun 2018 mulai melaksanakan program skrining melalui pemeriksaan rutin ibu hamil di puskesmas. Dari kegiatan tersebut, diperoleh prevalensi ibu hamil positif HBsAg 157 orang dan terbanyak berada di wilayah kerja Puskesmas Tamanan sebanyak 18 ibu hamil (Bidang P2, 2018).

Tingginya infeksi hepatitis B tersebut diduga karena rendahnya pengetahuan dan kesadaran ibu hamil terhadap penyakit hepatitis dan bahkan sebagian besar mungkin tidak memahami apa yang dimaksud dengan hepatitis. Pengidap infeksi HBV sering tidak mengetahui bahwa dirinya terinfeksi virus hepatitis karena infeksi $\mathrm{HV}$ sering tidak menimbulkan gejala dalam jangka panjang disebabkan adanya fase imun toleran (HbsAg dan DNA HBV yang positif tanpa gejala dan tanda ) dalam perkembangan infeksi $\mathrm{HBV}$ kronis (Sanityoso A, 2014).

Deteksi dini Hepatitis B pada ibu hamil dilaksanakan bersamaan dengan pemeriksaan HIV dan Sifilis. Di negara berkembang, termasuk indonesia, penularan VHB secara vertikal masih memegang peranan pentingdalam penyebaran VHB. Selain itu, 90\% anak yang tertular secara vertikal dari ibu dengan HBsAg (+) akan berkembang menjadi Hepatitis B kronik. Untuk itu, pencegahan penularan secara vertikal merupakan salah satu aspek yang paling penting dalam memutus rantai penularan hepatitis B (DepKes RI 2012 ).

\begin{tabular}{llr}
\multicolumn{1}{c}{ Dari } & hasil & penelitian \\
menunjukkan & bahwa & terdapa \\
perbedaan rata-rata signifikan sikap \\
responden sebelum dan & sesudah \\
diberikan & paket & edukasi \\
preeklampsia & pada & kelompok
\end{tabular} intervensi dan kontrol. Hal ini di buktikan nilai $\mathrm{P}$ value sikap yang diperoleh dari hasil pengujian perbedaan rata-rata sebesar $0,004<0,05$ yang berarti rata-rata sikap sebelum dan sesudah diberikan paket edukasi preeklampsia pada kelompok intervensi berbeda secara signifikan pada kelompok control(kholisotin, 2017)

Beberapa faktor diduga berperan dalam pelaksanaan pemeriksaan HbsAg pada ibu hamil diantaranya pendidikan, pekerjaan, pengetahuan 
ibu tentang pemeriksaan $\mathrm{HbsAg}$, persepsi akan kerentanan, persepsi akan keparahan, persepsi akan manfaat, persepsi akan hambatan, tempat pemberi layanan pemeriksaan HbsAg, dukungan keluarga dan pelayanan petugas kesehatan (WHO, 2010).

Kesadaran individu terhadap suatu program kesehatan dipengaruhi oleh berbagai faktor dan salah satunya adalah faktor pengetahuan dan sikap ibu hamil pada program kesehatan itu sendiri (Notoatmodjo, 2012b).

Tiga faktor yang memengaruhi kepatuhan ibu hamildalam pemeriksaan HBsAg yaitu perilaku ibu dalam pemanfaatan pelayanan kesehatan selama kehamilan (ANC), akses ke pelayanan kesehatan dan tingkat pendidikan ibu (Sofie, N., Wilopo, S.A.. \& Ismail. D., 2004).

Persalinan ibu yang positif HBsAg juga merupakan resiko terjadinya penularan hepatitis B secara horizontal. Pemeriksaan HBsAg pada ibu hamil sebelum melakukan persalinan merupakan skrining adanya penularan hepatitis B secara vertikal. Resiko penularan hepatitis B dengan hasil pemeriksaanHBsAg positif, berbahaya terhadap janinyang dikandung ibu karena dapat mengancam keselamatan ibu dan bayinya. Selain berbahaya terhadap ibu dan janin, bahaya penularan infeksi hepatitis $B$ juga dapat mengancam tenaga medis yang menolong ibu saat proses persalinan terjadi (Radji Maksum dalam Hernando dkk, 2018).

Menurut Permenkes nomor 53 tahun 2015 tentang penanggulangan hepatitis virus, bahwa deteksi dini hepatitis B (DDHB) ditawarkan kepada setiap ibu hamil yang datang ke fasilitas pelayanan kesehatan untuk melakukan pemeriksaan hepatitis B dan HIV secara terintegrasi di layanan kesehatan ibu dan anak (KIA) yang tersedia di layanan pencegahan penularan dari ibu ke anak untuk penyakit HIV dan Hepatitis (Bidang P2, 2018).

Survey pendahuluan juga peneliti lakukan terhadap beberapa ibu hamil baik yang datang ke Puskesmas maupun yang berada di wilayah kerja puskesmas, dan sebagian besar tidak mengetahui tentang hepatitis B dalam kehamilan dan bahwa mereka harus menjalani skrining HBsAg dalam kehamilan. Pengetahuan mereka hanya sebatas pemeriksaan darah di puskesmas untuk deteksi HIV dan Penyakit Menular Seksual lainnya.

Peningkatan pengetahuan ibu hamil tentang skrining HBsAg dirasa perlu untuk membentuk pengetahuan dan sikap positif terhadap pencegahan penularan hepatitis dari ibu ke janin dan mencegah komplikasi yang timbul dari hepatitis B kronis.

\section{METODE PENELITIAN}

Desain penelitian yang digunakan adalah desain preeksperiment dengan pendekatan one group pretest-posttest. Desain ini melibatkan satu kelompok yang diberi pre-test $(\mathrm{O})$, diberi Paket Edukasi HbSAg (X) dan diberi posttest. Keberhasilan paket edukasi $\mathrm{HbSAg}$ ditentukan dengan membandingkan nilai pre-testdan nilai post-test untuk mengungkapkan hubungan sebab akibat dengan cara melibatkan satu subjek. Kelompok Subjek di observasi sebelum dilakukan intervensi, kemudian diobservasi lagi setelah intervensi. Tiap subyek penelitian hanya 
diobservasi satu kali saja dan pengukuran variable diukur dan dianalisis saat pemeriksaan atau pengkajian saja dengan menggunakan bentuk rancangan pre test - post test design. Pada rancangan ini tidak ada kelompok pembanding, tetapi telah dilakukan observasi pertama (pre test) yang memungkinkan menguji perubahan yang terjadi setelah dilakukan eksperimen.

Populasi penelitian adalah seluruh ibu hamil trimester I yang berada di wilayah kerja Puskesmas Tamanan Kecamatan Tamanan. Berdasarkan data yang didapat Jumlah ibu hamil 35 orang. Pada penelitian ini sampel yang di ambil adalah sampel yang telah memenuhi kriteria inklusi. Teknik yang digunakan dalam pengambilan sampel adalah total sampling dengan mengambil semua sampel yang ada pada saat penelitian.

\section{HASIL}

Sebanyak 35 responden berpatisipasi dalam penelitian ini. Berdasarkan tabel 1 menunjukkan bahwa sebagian besar responden berada pada kelompok usia 17 - 25 tahun sebanyak 19 orang $(54,29 \%)$, mayoritas responden primipara sebanyak 23 orang $(65,71 \%)$, sebagian besar responden berpendidikan SMP sebanyak 14 orang (40\%), dan sebagian besar responden tidak bekerja atau ibu rumah tangga (IRT) sebanyak 21 orang $(60 \%)$.

Tingkat pengetahuan ibu hamil sebagian besar jumlah responden dalam kategori pengetahuan kurang sebelum intervensi sebanyak 18 orang $(51,43 \%)$, sedangkan setelah intervensi terjadi peningkatan pengetahuan baik sebanyak 24 orang $(68,57 \%)$. Begitu pula terkait sikap ibu hamil sebelum intervensi sebagian besar ibu hamil mempunyai sikap negatif sebanyak 21 orang $(60 \%)$, setelah intervensi terjadi peningkatan sikap positif sebanyak 32 orang $(91,43 \%)$ (Tabel 2).

Nilai rata-rata tingkat pengetahuan responden sebelum diberikan paket edukasi adalah 46,86 dan setelah mendapatkan paket edukasi HbsAg meningkat menjadi 76,00. Hasil uji wilcoxone menunjukan nilai signifikan sebesar $0,000<0,05$ menunjukan bahwa ada beda pengetahuan ibu hamil Trimester 1 tentang HBsAg sebelum dan sesuah intervensi. Begitu pula pada nilai rata-rata sikap responden sebelum diberikan paket edukasi adalah 4,34 dan setelah mendapatkan paket edukasi HbsAg meningkat menjadi 6,40. Hasil uji wilcoxone menunjukan nilai signifikan sebesar $0,000<0,05$ yang berarti ada beda sikap ibu hamil trimester 1 tentang HBsAg sebelum dan sesudah intervensi (Tabel 3).

\section{PEMBAHASAN}

Pengetahuan merupakan seluruh kemampuan individu untuk berfikir secara terarah dan efektif.sehingga orang yang mempunyai pengetahuan tinggi akan mudah menyerap informasi, saran, dan nasihat. Menurut Notoatmodjo, pengetahuan atau kognitif merupakan domain yang sangat penting dalam membentuk perilaku dan sikap seseorang karena perilaku dan sikap didasari oleh pengetahuan (Notoatmodjo, 2012b). 
Tabel 1. Karakteristik Responden $(\mathrm{n}=35)$

\begin{tabular}{llcc}
\hline Karakteristik & & n & \% \\
\hline Usia & 17-25 tahun & 19 & 54,29 \\
& 26-35 tahun & 7 & 20 \\
Paritas & 36-45 tahun & 9 & 25,71 \\
& Primipara & 23 & 65,71 \\
Pendidikan & Multipara & 12 & 34,29 \\
& SD & 9 & 25,71 \\
& SMP & 14 & 40 \\
& SMA & 9 & 25,71 \\
Pekerjaan & PT & 3 & 8,58 \\
& Ibu rumah tangga & 21 & 60 \\
& Wiraswasta & 13 & 37,14 \\
& PNS & 1 & 2,86 \\
\hline
\end{tabular}

Tabel 2. Pengetahuan dan Sikap Ibu Hamil Sebelum dan Sesudah Intervensi $(\mathrm{n}=35)$

\begin{tabular}{lcc}
\hline Variabel & n & \% \\
\hline Sebelum Intervensi & & \\
Pengetahuan & 6 & 17,14 \\
$\quad$ Baik & 11 & 31,43 \\
Cukup & 18 & 51,43 \\
$\quad$ Kurang & & 65,71 \\
Sikap & 14 & 40 \\
$\quad$ Positif & 21 & 60 \\
$\quad$ Negatif & & \\
Sesudah Intervensi & & 68,57 \\
Pengetahuan & 24 & 31,43 \\
$\quad$ Baik & 11 & 0 \\
$\quad$ Cukup & 0 & \\
Kurang & & 91,43 \\
Sikap & 32 & 8,57 \\
Positif & 3 & \\
Negatif & & \\
\hline
\end{tabular}

Tabel 3. Analisis Perbedaan Pengetahuan dan Sikap Sebelum dan Sesudah Intervensi $(\mathrm{n}=35)$

\begin{tabular}{llll}
\hline \multirow{2}{*}{ Variabel } & \multicolumn{2}{c}{ Sebelum Intervensi } & \multicolumn{2}{c}{ Sesudah Intervensi } & \multirow{2}{*}{$\boldsymbol{P}$ Value } \\
\cline { 2 - 4 } & \multicolumn{2}{c}{ Mean } & \multicolumn{2}{c}{ Mean } & \\
\hline Pengetahuan & 46,86 & 76,00 & 0,000 \\
Sikap & 4,34 & 6,40 & 0,000 \\
\hline
\end{tabular}

Hasil penelitian ini sejalan dengan teori tersebut yaitu pengetahuan responden terhadap HBsAg berhubungan dengan sikap dalam pemeriksaan HBsAg. Tingkat pendidikan mempengaruhi kemampuan dan perkembangan seseorang secara berkesinambungan. Pendidikan dasar diberikan dengan tujuan sebagai dasar hidup dalam pengetahuan dan ketrampilan dasar kemudian dilanjutkan dengan 
pendidikan lanjutan (Tirtarahardja., 2015)

Hasil penelitian ini juga sesuai dengan penelitian yang dilakukan Mesfa Juniny, yang mendapatkan hasil penelitian bahwa ada pengaruh penyuluhan $\mathrm{HbsAg}$ terhadap pengetahuan ibu hamil Artinya, pemberian paket edukasi $\mathrm{HbsAg}$ sangat mempengaruhi pengetahuan dan sikap sesorang maka dalam penelitian ini ada hubungan bermakna antara pemberian paket edukasi HbsAg terhadap pengetahuan dan sikap seseorang (Mesfa Juniny, 2016).

Menurut Iqbal, bertambahnya usia maka produktivitasnya ikut menurun, hal ini disebabkan ketrampilan fisik akan berkurang seiring pertambahan usia tetapi pengalaman dan kematangan jiwa akan semakin meningkat (Mubarak, 2011). Pada penelitian ini secara statistik didapatkan hasil bahwa faktor usia tidak berpengaruh secara bermakna terhadap tingkat pengetahuan ibu hamil terhadap pemeriksaan HbsAg. Hal ini tidak menutup kemungkinan karena pengetahuan yang ia miliki bisa saja berasal dari pengetahuan yang dimilikinya sebelumnya, pengalaman pribadi maupun orang lain dan beberapa faktor lainnya yang dapat membentuk pengetahuan seseorang dalam jangka waktu yang lama dan akan bertahan. Dalam teorinya, usia mempengaruhi perkembangan daya tangkap dan pola pikir seseorang, semakin tua usia seseorang maka proses-proses perkembangan mentalnya bertambah baik, akan tetapi pada usia tertentu, bertambahnya proses perkembangan mental ini tidak secepat seperti ketika berumur belasan tahun. Bertambahnya umur seseorang dapat berpengaruh pada pertambahan pengetahuan yang diperolehnya.

Hasil penelitian ini sejalan dengan penelitian yang dilakukan Kholisotin, menunjukkan bahwa terdapat pengaruh yang signifikan pengetahuan responden sebelum dan setelah diberikan paket edukasi preeklampsia pada ibu hamil yang beresiko mengalami preeklampsia dengan nilai $P$ value $\mathrm{P}=0,002$ ( $\mathrm{P}<0,05)$. (Kholisotin, 2017). Salah satu faktor yang mempengaruhi pengetahuan pada responden adalah pendidikan terakhir.Berdasarkan karakteristik responden di Puskesmas Tamanan menunjukan bahwa responden terbanyak adalah ibu hamil pada kelompok tingkat pendidikan SMP sebanyak 14 orang (40\%).Pendidikan merupakan salah satu faktor yang menentukan luasnya wawasan dan pengetahuan seseorang, dengan adanya pendidikan yang sebagian besar SMP maka berpengaruh terhadap peningkatan pengetahuan tentang HBsAg.Semakin tinggi pendidikan seseorang maka diharapkan semakin mudah seseorang menyerap pengetahuan yang diperolehnya. Seseorang yang berpendidikan rendah tidak berarti berpengetahuan rendah pula.Peningkatan pengetahuan dapat juga diperoleh pada pendidikan non formal misalnya melalui kegiatan pemberian informasi yaitu penyuluhan.sementara pengetahuan merupakan hasil tahu dan terjadi setelah orang melakukan penginderaan terhadap objek tertentu, penginderaan terjadi melalui panca indera manusia yaitu indera penglihatan, pendengaran, penciuman, rasa dan raba.

Sikap akan terbentuk dengan lebih positif apabila seorang telah 
memiliki pengalaman pribadi sebelumnya. Menurut Middlebrook, tidak adanya pengalaman sama sekali dengan suatu objek psikologis cenderung akan membentuk sikap negatif terhadap objek tersebut(Middlebrook, 2010). Bagi primigravida kehamilan merupakan pengalaman baru yang menyebabkan perubahan psikologis yang besar. Faktor psikologis yang menyebabkan kekhawatiran berkaitan dengan kesiapan seorang wanita dengan perubahan fisik dan mental yang dialami selama masa kehamilan (Bobak, I.M.,\&Lowdermilk, 2005).

Faktor pendukung lain yaitu pekerjaan responden yang sebagian besar adalah ibu rumah tangga (IRT) sebanyak 21 orang $(60 \%)$, ibu rumah tangga berpengaruh terhadap status ekonomi keluarga yang selanjutnya akan berpengaruh pada kemampuan ibu mendapatkan sarana untuk memperoleh informasi termasuk dalam hal adaptasi kehamilan. Hal ini sejalan dengan pendapat Notoatmodjo semakin tinggi tingkat sosial ekonomi seseorang, semakin mudah pula seseorang menerima informasi baru (Notoatmodjo, 2012a). Menurut Notoadmodjo, umur mempengaruhi daya tangkap dan pola pikir seseorang. Pada usia madya individu akan lebih berperan aktif dalam masyarakat dan kehidupan sosial serta lebih banyak melakukan persiapan untuk menghadapi pemeriksaan pada masa kehamilannya (Notoatmodjo, 2012a). Faktor usia ibu yang terlalu muda kurang dari 20 tahun dan terlalu tua lebih dari 35 tahun, termasuk kelompok berisiko yang menambah peluang kematian ibu semakin besar. Apabila seorang ibu hamil memiliki pengetahuan yang lebih tentang adaptasi pemeriksaan pada masa kehamilan maka kemungkinan besar ibu akan berpikir menentukan sikap untuk mencegah, menghindari atau mengatasi masalah dalam kehamilan (DepKes RI, 2017).

Dampak sikap cukup dalam menghadapi adaptasi pemeriksaan HbsAg pada masa kehamilan mengakibatkan kurangnya pemahaman masalah fisiologis maupun psikologis yang terjadi. Masalah kesehatan fisiologis dan psikologis dalam periode kehamilan yang tidak dikelola dengan baik dapat mengakibatkan komplikasi bagi ibu maupun janin (Kusmiyati, Yuni, 2009). Hal ini dikarenakan adanya kurangnya pengetahuan responden tentang adaptasi kehamilan. Sesuai dengan teori yang dikemukakan oleh Green dalam Notoatmodjo bahwa sikap dapat dipengaruhi oleh faktor predisposisi yang salah satunya pengetahuan (Notoatmodjo, 2012b).

Pendidikan mempengaruhi proses belajar, semakin tinggi pendidikan seseorang semakin mudah orang tersebut untuk menerima informasi. Semakin banyak informasi yang masuk semakin banyak pula pengetahuan yang didapat tentang kesehatan yang mempengaruhi sikap seseorang (Notoatmodjo, 2012a). Intervensi berupa penyuluhan ternyata dapat mempengaruhi peningkatan sikap seseorang terhadap sesuatu hal. Sikap ibu hamil tentang $\mathrm{HbsAg}$ dipengaruhi oleh pengetahuan ibu hamil terhadap hal yang sama, serta ada kemungkinan juga sikap yang sudah ada terbentuk karena adanya faktor sosial budaya di lingkungan tempat tinggal.

Hasil penelitian ini juga sesuai dengan penelitian yang dilakukan Kholisotin, Pengetahuan atau 
pemahaman mengenai preeklampsia melalui paket edukasi membuat ibu hamil yang beresiko mengalami preeklampsia dapat meningkatkan pengetahuannya, dengan meningkatnya pengetahuan ibu hamil dapat mempengaruhi sikap dan tindakannya dalam memelihara kesehatan sehingga terjadinya preeklampsia/eklampsi dapat di cegah pada kehamilannya (Kholisotin, 2017). Menurut Purwanto sikap bukan dibawa sejak lahir, melainkan dibentuk dan dipelajari sepanjang perjalanan perkembangan orang tersebut dalam hubungan dengan objeknya. Dalam hal ini pengetahuan yang diberikan melalui paket edukasi kepada ibu hamil membantu pembentukan sikap pada ibu ibu hamil terhadap hal yang sama.

Menurut Budiman dan Riyanto (2013), pengetahuan sangat erat kaitannya dengan pendidikan. Pendidikan adalah sebuah proses pengubahan sikap dan tatalaku seseorang atau kelompok dan juga usaha mendewasakan manusia melalui upaya pengajaran dan pelatihan. Dengan pendidikan tinggi, maka seseorang akan cenderung untuk mendapatkan informasi baikdari orang lain maupun dari media massa. Semakin banyak informasi yang masuk semakin banyak pula pengetahuan yang didapatkan. Hasil penelitian ini didukung oleh hasil penelitian Legiati., et al (2012), yang menyatakan bahwa pengetahuan ibu hamil tentang pemeriksaan hepatitis B dan sifilis sangat penting dalam upaya pencegahan penularan penyakit hepatitis B dan sifilis dari ibu ke anak. Pengetahuan yang rendah tentang hal tersebut akan mempengaruhi ibu dalam memanfaatkan layanan pemeriksaan hepatitis B dan sifilis (Dr. J.B Suharjo B Cahyono, 2010).

Hasil penelitianVitasari \& Nur (2015), menunjukkan bahwa ada hubungan antara pengetahuan, sikap tentang hepatitis B dan motivasi dari bidan dengan kesediaan melakukan penyuluhan (Sofie, N., Wilopo, S.A.. \& Ismail. D., 2004). Berdasarkan Teori Allport, menjelaskan bahwa sikap itu mempunyai 3 komponen pokok salah satunya kecenderungan untuk bertindak, ketiga komponen ini secara bersama-sama membentuk sikap yang utuh (total attitude).

Dalam penentuan sikap ini, pengetahuan, berfikir, keyakinan, dan emosi memegang peranan penting.Sikap merupakan reaksi atau respons seseorang yang masih tertutup terhadap suatu stimulus atau objek, dimana sikap ini terjadi dari menerima, merespon, menghargai, dan bertanggung jawab. Sebagai contoh dalam penelitian ini, responden yang mengetahui tentang HbsAg akan membawa responden untuk berfikir dan berusaha supaya melakukan pemeriksaan HbsAg. Dalam berfikir ini komponen emosi dan keyakinan ikut bekerja sehingga responden tersebut bemiat akan melakukan pemeriksaan HbsAg. Hasil penelitian ini sejalan dengan teori tersebut yaitu pemberian paket edukasi HbsAg berhubungan dengan pengetahuan dan sikap ibu hamil. Hasil penelitian ini mendukung yang di ungkap Notoatmodjo, bahwa penentuan sikap secara terintegritas dipengaruhi oleh pengetahuan, wawasan, wacana, pikiran, pengalaman, keyakinan dan emosi dari ibu. Pengetahuan dan sikap ibu hamil dapat di kaji dari berbagai perspektif maupun sumber informasi 
yang mendukung (Notoatmodjo, 2012b).

Hasil penelitian ini sesuai dengan penelitian yang dilakukan Gunawan (2013) dengan nilai $p$ valuenya $<0,05$ yaitu ada hubungan antara penyuluhan terhadap pengetahuan sikap ibu hamil tentang HbsAg. Artinya, pengetahuan seorang ibu sangat mempengaruhi untuk sikap ibu. Sikap positif yang mendukungini lebih banyak menyadari dari manfaat pemeriksaan HbsAg itu sendiri (Mubarak, 2011). Hasil penelitian ini juga sesuai dengan penelitian yang dilakukan Kholisotin, pengetahuan atau pemahaman mengenai preeklampsia melalui paket edukasi membuat ibu hamil yang beresiko mengalami preeklampsia dapat meningkatkan pengetahuannya, dengan meningkatnya pengetahuan ibu hamil dapat mempengaruhi sikap dan tindakannya dalam memelihara kesehatan sehingga terjadinya preeklampsia/eklampsi dapat di cegah pada kehamilannya (Kholisotin, 2017).

\section{SIMPULAN}

Paket edukasi HbsAg dapat meningkatkan pengetahuan dan sikap ibu hamil trimester 1 tentang pentingya HbsAg selama masa kehamilan. Edukasi yang dilakukan dengan terstruktur, mempunyai perencanaan yang baik, dan menggunakan strategi yang tepat merupakan kunci utama dalam keberhasilan meningkatkan pengetahuan dan sikap.

\section{SARAN}

Paket edukasi ini sebaiknya digunakan oleh petugas kesehatan sesuai dengan intruksi yang telah dibuat. Oleh sebab itu sebaiknya petugas menyusun Standar Operasional Prosedur (SOP) terkait paket edukasi ini sebelum memberikan intervensi, yang kemudian ditetapkan dan disahkan sehingga intervensi paket edukasi ini dapat diberikan pada ibu hamil.

\section{DAFTAR PUSTAKA}

\section{Abdul Gani Soulissa (2014) 'Hubungan kehamilan dan penyaki periodontal', dalam jurnal PDGI, 3.}

Bidang P2 (2018) 'Rekap Ibu Hamil dengan Pemeriksaan HbsAg Positif', Dikes Bondowoso.

Bobak, I.M.,\&Lowdermilk, D. L. (2005) Buku Ajar Keperawata Maternitas Edisi 4. Jakarta: EGC.

DepKes RI (2017) 'Profil Kesehatan Indonesia 2017', Badan Penerbit Dinas Kesehatan Indonesia.

Dr. J.B Suharjo B Cahyono (2010) Cegah Kanker Hati. Jogyakarta: Kanisius.

Kholisotin (2017) 'Efektifitas Pake Edukasi Preeklampsia Terhadap Pengetahuan, Sikap, dan Keterampilan Ibu Hamil yang Beresiko Mengalami Preeklampsia diKabupaten Situbondo', Jurnal Keperawatan.

Kusmiyati, Yuni, dkk. (2009) Perawatan Ibu Hamil. Jogyakarta: Fitramaya.

Mesfa Juniny (2016) Hepatitis $b$ dalam Naskah Publikasi, Kejadian Infeksi Hepatitis B pada Anak Yang dilahirkan Oleh Ibu dengan Positif HbsAg. Program Pascasarjana Fakultas Kedokteran Universitas GadjahMada, Yogyakarta. 
Middlebrook, P. N. (2010) Social Psychology and Modern Life. New York: Alfred A.Knopf Inc.

Mubarak, W. I. (2011) Ilmu Keperawatan Komunitas 2. Teori dan Aplikasi dalam Praktik dengan Pendekatan Asuhan Keperawatan Komunitas, Gerontik dan Keluarga. Jakarta: Sagung Seto.

Notoatmodjo, S. (2012a) Metodologi Penelitian Kesehatan. Jakarta: Rineka Cipta.

Notoatmodjo, S. (2012b) Pendidikan dan Perilaku Kesehatan. Jakarta: Rineka Cipta.

Radji Maksum dalam Hernando dkk (2018)

'Kesehatan Pemeriksaan Hepatitis B surface Antigen (HbsAg) dan Anti Hbs Pada Ibu Hamil',
Jurnal Riset, 1, pp. 80-84.

Sanityoso A, C. G. (2014) Ilmu Penyakit Dalam (Hepatitis Viral Akut) Jilid II Edisi VI. Jakarta: Interna Publishing.

Sofie, N., Wilopo, S.A.. \& Ismail. D. (2004) 'Hubungan Perilaku ibu dalam Memanfaatkan Pelayanan Kesehatan Selama Kehamilan dengan Kepatuhan Ibu hamil dalam pemeriksaan BhsAg', Berita Kedokteran Masyarakat XX, pp. 97-103.

Tirtarahardja. (2015) Hubungan Antara Tingkat Pengetahuan, Sikap Tentang pemeriksaan HBsAg Pada Ibu Hamil (di Puskesmas Campurejo, KotaKediri). Universitas Surakarta.

WHO (2010) 'Behavioral Factors in Immunization for Pregnancy', Geneva. 